\title{
Original DocumentsGrant by Ingelram Lord of Coucy to the King, of the Reversion of the Lands of Johanna who was Wife of John De Coupeland Deceased
}

Joseph Bain F.S.A. Scot.

To cite this article: Joseph Bain F.S.A. Scot. (1878) Original DocumentsGrant by Ingelram Lord of Coucy to the King, of the Reversion of the Lands of Johanna who was Wife of John De Coupeland Deceased, Archaeological Journal, 35:1, 166-168, DOI: 10.1080/00665983.1878.10851840

To link to this article: http://dx.doi.org/10.1080/00665983.1878.10851840

$$
\text { 曲 Published online: } 14 \text { Jul } 2014 .
$$

Submit your article to this journal ¿ 


\title{
Origual Doruments
}

Contributed by JOSEPH BAIN, F.S.A. Scot.

\begin{abstract}
GRANT BY INGELRAM LORD OF COUCY TO THE KING, OF THE REVERSION OF THE LANDS OF JOHANNA WHO WAS WIFE OF JOHN DE COUPELAND DECEASED.
\end{abstract}

\section{6th Nov., 41st Eduard III. (1367).}

"Sciant presentes et futuri quod ego Ingelramus Dominus de Coucy et Comes Bedefordie ex certis et evidentibus causis concessi pro me et heredibus meis quod omnia maneria terre et tenementa que nobilis domina Johanna que fuit uxor Johannis de Coupeland tenet ad terminum vite sue et que post decessum ipsius Johanne al me et heredes meos renerti deberent post mortem ipsius Johanne Excellentissimo principi et domino meo domino Edwardo Regi Anglie Illustri et heredibus suis remaneant habenda et tenenda sibi et heredibus suis una cum feodis militum aduocacionibus ecclesiarum hospitalium domorum Religiosarum vicariorum et capellarum parcis forestis chaceis boscis warennis piscariis moris marisiis turbariis pratis pascuis pasturis seruiciis tenencium tam liberorum quam natiuorum libertatibus regalitatibus escactis wardis maritagiis releuiis commoditatibus profitiis et ommibus aliis ad predicta maneria terras et tenementa qualitercumque spectantibus sine pertinentibus imperpetuum Et ego predictus Ingelramus et heredes mei ommia predicta maneria terras et tenementa cum pertinentibus suis predictis quibuscunque prefato domino meo Regi et heredibus suis Warantizabimus et contra omnes gentes defenclemus imperpetuum In cuius rei testimonium huic presenti carte sigillum meum apposui Hiis testibus Venerabilibus patribus W[illelmo] (de Edyndon) Wyntoniensi Cancellario | S[imone] (Langham) Eliensi Thesaurario Anglie | Episcopis | Leonello Clarencie Johanne Lancastrie Ducibus | Edmundo Cantebrigie Ricardo Arundellie Comitibus | Edwardo le Despenser domino de Glamorgan Bartholomeo de Burgherssh et Johamme atte Lee Senescallo hospicii ipsius clomini Regis et aliis Data Londonio vicesimo sexto die Nouembris Anno Regni Domini mei Regis Edwardi supradicti quadragesimo primo."

\section{(Indorsed.)}

"Irrotulata in clorso claus" cancellarie Regis. Et tricesimo mense Nouembris anno regni sui quadragesimo primo."

The seal, in red wax, is attached to the tag, and exhibits the three bars vairee of the De Concys, above which is a helmet affrontee, with mantlings, from which springs the crest, a panache, or plume of feathers. The legend is imperfect:. . . . "Domini cle Couci" is all that can be read. 


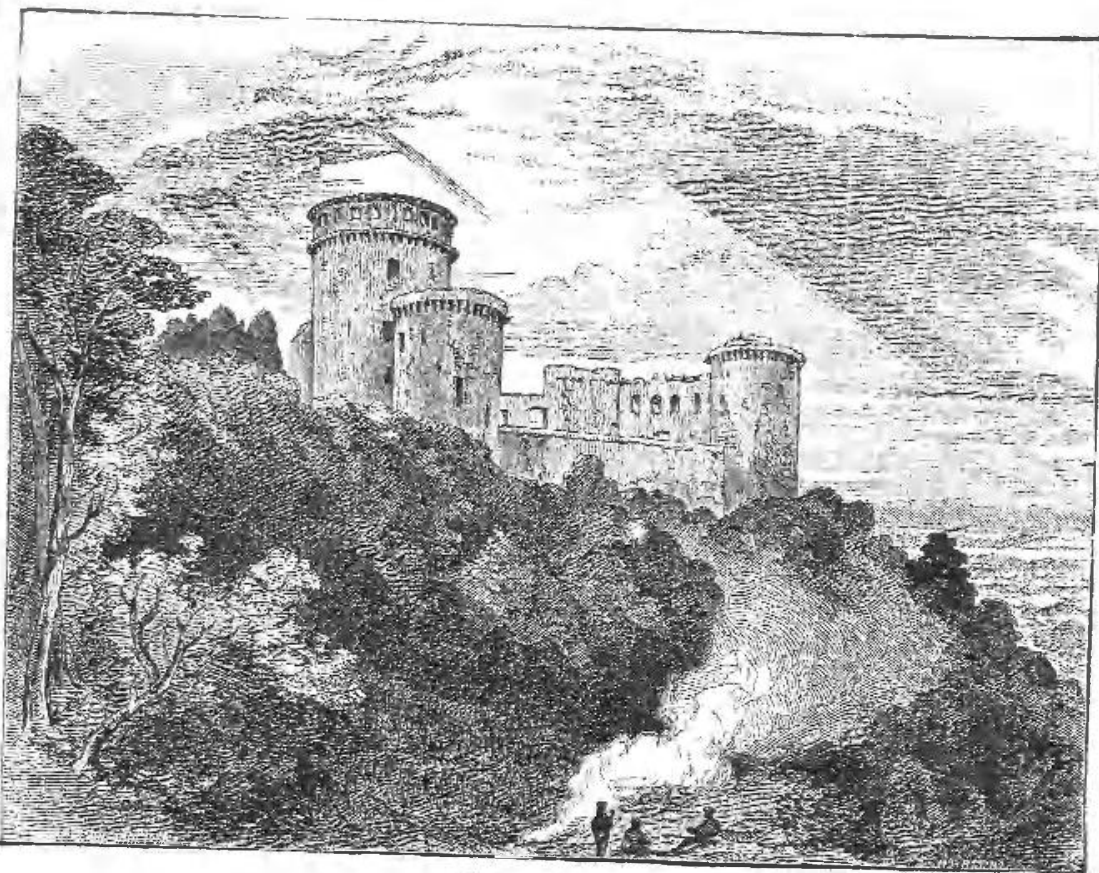

"lwath Cots: 
There is nothing to shew in what shire the lands lay. The document is contributed, as its granter bore the dignity of Earl of Bedford, in close neighbourhood to Northampton. His own family name recalls the days when the Turk was the terror of Christendom.

Ingelram (or Enguerrand), the seventh Sieur de Couci of that Christian name, was the last male of his illustrious house, which was accustomed to ally with princes.

Their proud motto--

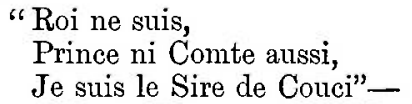

shewed a spirit above titles. Enguerrand VII was one of the hostages in England for the ransom of King John. While there he married Isabella, daughter of Edward III, who created him Earl of Bedford and Count of Soissons. After his father-in-law's deatb, he allowed the Princess to return to England, and also is said to have returned his Order of the Garter to Richard II, preferring to retain his allegiance to the French king, while renouncing that of England. In the autumn of 1375 he led an army of 40,000 men into the Aargau to vindicate the right of his mother, a daughter of the House of Austria, to her dowry lands in the cantons of Berne and Luzerne. Though the force was composed of soldiers of fortune from nearly all the countries of Europe, the Swiss called them Englanders, and the traditions of the country still point to the "English barrow" of Buttisholz near Luzerne as a memorial of De Couci's defeat.

Those who have read Anne of Geierstein cannot fail to remember how Sir Walter Scott makes use of the tradition. De Couci left two daughters by the Princess, the younger of whom married Robert de Vere Duke of Ireland, the favourite of Richard II. ${ }^{1} \mathrm{He}$ had another daughter by a second wife, who married her cousin Philip of Burgundy, Comte de Nevers. The last Lord of Couci was one of the leaders of the Christian army, which was so signally defeated by the Sultan Bajazet at the battle of Nicopolis in 1394, when he was made a prisoner. He died in captivity at Brusa in Bithynia on 18th February 1396-7, the last male of his family. Robert de Bar, son of his eldest daughter Marie, was compelled in 1400 to sell the great domain of Coucy to Louis first Duke of Orleans for 400,000 livres. It remained with the royal family of France up to the great Revolution. The brother of Louis XIV was Lord of Coucy, and its last seigneur was "Egalite" Orleans. The colossal keep of "Couci le Chateau," which, irrespective of the high ground whereon it stands, towers above the plains of the Aisne to the height of 200 feet, measured from moat to water table, has been described by M. de Caumont, and more recently by M. Viollet-le Duc in an interesting monograph (Paris, 1857, $8^{\circ}$ ). The great architect, who has done so

1 Robert de Vere died in exile at Louvain in the Low Country, from the effects of a wound received at a hunting party in that neighbourhood. His friends, Sir John of Lancaster and others, wished to bury him in the Church of the Augustins there, which was resisted by the Dean and Chapter of St. Peter's Church, who claimed his body as their parishioner.

ror. $\mathrm{XxxV}$,
This curious dispute was settled in favour of the parish church by John of Bavaria, Bishop Elect of Liegge on 5th July 1394, under a Papal Brief of Boniface IX, directed to the Bishop, and the Provosts of St. George of Cologne, and St. John of Utrecht, on the 24 th February previous. - (Annales de l'Academie d'Ar'. cheologie de Belgique, vol. vii, p. 95). 
much to perpetuate the glories of feudal France, says, that of all those known to him, this donjon is the largest, most complete, anil strongest. It appears to have been built about 1220 by Enguerrand (third of the name) Lord of Coucy. On its second storey is situated the great hall, surrounded by a gallery. In this hall 1,200 to 1,500 men could be assembled to receive general orders. "Nothing;" says M. Viollet-le Duc, with enthusiasm, "in the monuments of Roman antiquity or in our own time is so grand as this beautiful structure, or so impressed with the stamp of power. Everything of general use seems to have been intended for a race larger than man. The benches are two feet high; the steps twelve to fifteen inches; the window sills three feet and a half, and doorways in proportion." Its founder, the third Enguerrand, was one of the grandest figures of the feudal age. Fifty knights with their followers formed his body guard of $500 \mathrm{men}$, independently of the vassals who owed him suit and service. Even Philip Augustus of France is said to have replied to the Chapter of Rheims when they implored protection from him, that he would pray the Sire de Couci to leave them unmolested, but could do no more.

From the terms of the charter it may be gathered that Johanna de Coupeland was not dead. The word "tenet" would imply that she was in possession at its date. The grant indeed also possibly warrants the supposition that the Lord of Coucy was in the year 1367 meditating the return to his continental allegiance, and resignation of that to his fatherin-law, which took place ten years later.

It does not appear whether John de Coupeland was the same person as the Northumbrian squire who captured David King of Scots at Neville's Cross in 1346. The Northumbrian, as may be seen from entries in the Fodera, was made a knight banneret, and handsomely rewarded with lands by the King. The John de Coupeland of the present charter is not styled a knight. The surname is however a north country one, and this omission of the style may have been accidental.

The original is rendered without contractions. It is preserved among the Exchequer Miscellanea in the Public Record Office, London. 